radioactive materials as aids to research; the handling and treatment of milk; the manufacture and quality of cheese; and the nutritional value of milk and dairy products. Further information can be obtained from Mr. J. A. Irvine, National Institute for Research in Dairying, Shinfield, Reading, Berks.

\section{Geography of South-East Asia}

A OONFERENoE of South-East Asian geographers sponsored by the International Geographical Union and the University of Malaya will be held in Kuala Lumpur during April 2-23, 1962. The conference will direct attention to geographical themes of immediate relevance in Malaya and South-East Asia, thereby providing data for assessing past practices and future policies in the region and in the humid tropics generally. It will also bring together geographers and other specialists to stimulate research and to promote the communication of information. The programme of the conference will include major sessions on: meteorology and climate of East and South-east Asia; geomorphology, geology and mineral resources; agricultural resources, soils and landuse; population, migration, ethnic studies and urban geography of South-east Asia. Further information can be obtained from Prof. R. Ho, Department of Geography, University of Malaya, Kuala Lumpur.

\section{Blood Transfusion Congress}

THE fourth national congress on "Blood Transfusion", arranged by the Société Nationale de Transfusion Sanguine in conjunction with the Société Française d'Hématologie, the Asociación de Hematologia y Hemoteriapia de Barcelone and the Centre d'Etudes des Problèmes Humains dans les Zones Arides, is to be held in Toulouse during June 11-14. The two main subjects to be diseussed during the congress are hæmolytic anæmia and the safety precautions necessary during blood transfusion. These will be followed by two colloquia: laboratory techniques, and the special problems arising in blood transfusion and hæmotherapy centres in tropical countries. Further information can be obtained from the Centre de Transfusion Sanguine et d'Hématologie, avenue de Grande-Bretagne, Toulouse.

\section{Waverley Gold Medal Essay Competition}

The Waverley Gold Medal Essay Competition is sponsored by Research Applied in Industry to encourage scientists to write clearly and comprehensibly about their work. The Medal, together with $£ 100$, will be awarded for the best essay of about 3,000 words deseribing a recent project or practical develop. ment in pure or applied science, giving an outline of the scientific background, the experimental basis and the potential or actual application of the idea to industry or its importance to society. A second prize of $£ 50$ will also be awarded, and a special prize of $£ 50$ for the best entry from a competitor under the age of thirty on July 31 . Entry forms and further information can be obtained from the Editor of Research Applied in Industry, 88 Kingsway, London, W.C.2. The closing date for the competition is July 31.

\section{Announcements}

The Council of St. John's College, Cambridge, invite applications for a Meres Senior Studentship for medical research, tenable for between one and three years at the University of Cambridge or some nearby institution approved by the Council. The applicant must be a male graduate of a university, though not necessarily one admitted to a degree in medicine or surgery. Further information can be obtained from the Master, St. John's College, Cambridge. Applications must be received before October 1 .

A sxmposium on "The Significance of Selenium and Vitamin E in Nutrition", arranged by the Nutrition Society (Scottish Group), is to be held in the University of Glasgow on April 14. Further information can be obtained from Dr. D. G. Armstrong, Hannah Dairy Research Institute, Ayr.

THE fourth annual medical staff symposium of the Memorial Hospital of Long Beach, California, supported by a grant from the Merck, Sharp and Dohme Postgraduate Programme, is to be held at the Hospital on May 23. Further information can be obtained from Dr. G. X. Trimble, Memorial Hospital of Long Beach, Long Beach, California.

A MeEting of the British Biophysical Society is to be held in the University of Edinburgh during April 11-12. The programme will include two symposia on "Irreversible Thermodynamics and Membranc Transport, Particularly of Water" and "Supramolecular Structure in Relation to Biological Activity and Funetion". Further information ean be obtained from Dr. P. M. B. Walker, Department of Zoology, University of Edinburgh, West Mains Road, Edinburgh.

A CONFERENCE on "The Accuracy of Industrial Measurement of Length and Diameter", arranged by the National Physical Laboratory in conjunction with the Institution of Mechanical, Electrical and Production Engineers, will be held at the National Physical Laboratory during April 17-18. Further information can be obtained from Mr. B. S. W. Mann, Standards Division, National Physical Laboratory, Teddington, Middlesex.

A CONFERENCE on "Use of Case Studies in Education for Management", organized jointly by the Welsh College of Advanced Technology and the Comparative Administration Trust, is to be held at the College during April 5-7. The fee for the conference will be 10 gns., and further information can be obtained from the conference secretary, Mr. T. Boyce, Welsh College of Advanced Technology, Cathays Park, Cardiff.

A SHORT course on "Inorganic and Semi-Inorganic Polymers", arranged by the Department of Chemical Technology of the Bradford Institute of Technology, is to be held during May 25-26. Subjects to be discussed will include: inorganic polymers; boron-containing polymers; phosphorus-containing polymers; polyphosphonitrilic chlorides; silicon-nitrogen polymers; co-ordination polymers. Further information can be obtained from the Registrar, Bradford Institute of Technology, Bradford 7. The fee for the course will be $£ 110 s$.

Erratum. The authors of the article entitled "Penetration of Lipid Films by Compounds Preventing Liver Necrosis in Rats", which appears on p. 754 of the February 24 issue of Nature, regret that errors occur in Table 1. The heading of the final column shovld read, "An electrokinetic potential ( $\zeta)$ of $\pm 25 \mathrm{mV}$. on lipid micelles", and the fourth entry underneath " $\zeta \leqslant 5 \mathrm{mV}$, at $10^{-2}$ ". 